\title{
Rasayana Drugs in Ayurveda
}

\section{Vinay R Kadibagil*}

Department of Rasashastra and Bhaishajya Kalpana, SDM College of Ayurveda and Hospital, India

*Corresponding Author: Vinay R Kadibagil, Department of Rasashastra and Bhaishajya Kalpana, SDM College of Ayurveda and Hospital, India.

Received: January 24, 2022; Published: February 05, 2022

DOI: $10.55162 /$ MCPS.22.031

Entire living organisms will be attacked by agents which lead to diseases. Even smallest organism like bacteria have their own system for fighting against infection by viruses. This mechanism of self-defencing will be more complicated as organism becomes more advanced. The present infections need not just anti-microbial action but also should increase the immunity in a person. This is an approach and way to be adopted in the present scenario. Rasayana herbs refill the lost nutrients and enhance virility. In the present days, the whole process seems to be quite tedious and laborious and so a more balanced approach for proper utilization of Rasayana drugs is necessary for current society (Conboy, Edshteyn, \& Garivaltis, 2009; Mahdihassan, 1981; Puri, 2003b; Sharma, Chandola, Singh, \& Basisht, 2007; Shukla, 1971).

The concept of wellbeing is more important and comes with the understanding that there is more to health than absence of diseases (Sims, 2010). This concept will also apply to traditional food which will help to balance the health status of person. Rasayana concept is an ancient, commonly practiced therapy using ayurvedic drugs for treating diseases as well as for maintaining the health. (Ali, 1998; Kumar, Kuttan, \& Kuttan, 1999; Puri, 2003b; Sharma, Hanna, Kauffman, \& Newman, 1995; Shukla, 1971). Many researches have been done on drugs having Rasayana property and confirmed for their effect on the immune system, endocrinological benefits, antioxidant properties, memory and learning behaviour improvement, etc. Rasayana as immune-modulating agents hold a promising ability to activate the immune system without altering the normal physiological functioning.

\section{Volume 2 Issue 2 February 2022}

(c) All rights are reserved by Vinay R Kadibagil. 